は $9 \%$ にすきなかったが，姑息的黄㾇轅诚措置ある いは単開腹にとどまっだ症例では33\%の高率であっ た。この原因については勿論進行癌症例では, 肝障 害がより高度で全身状热も不良であったと考えられ ろか，全例が高度の黄㾝を発現していた膊道，喑大 部癌症例飞子いて，胆道切除のみならず膵頭十二指

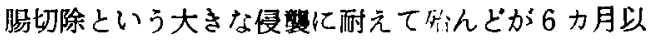
上生存し， 3 年生存列 6 経験されている。

との事実から，三の病変自体が肝障害の要因とな っている外科的黄疾にわいては, 畞汗の统出障害を 有效に除去寸る手術が行い得たか, 否かということ が手術死亡率の大さな因子であると考えられ，術前 閉塞性黄疸が高度であってい，手術によってこれを 解除し得た場合には，侵悲がかなり大きくとも致命 的な肝不全に宿ることは少ないので，現在予後不良 な勗道癌の治療成綪を向上させるには，術前後の処 置，麻醉管理，手術手技に細心の注意を払い，積極 的な腫㴼坚の切除と有効な朋道再建に努めることが 必要であると考える。

III-33. 胆道系疾患の手術成䋶に及ぼす黄㾝の意義 について

意恵医大 大井外科 ○河野明由 星 清 三䅹乙実 小田隆男 南谷信昭 内田 誠

䏣道系手術思者の術後成綪については，咋年の本 学会に発表したが，今回は術前黄疸について，この 有無，程度，期間等が手術成績に及ぼす影簘につい て検討し，併わせて，比較的難治であった重症黄疸 例について，その病態，治療成結を報告する。

外科的黄疸の発生形態は, 勿諭, 閉塞の部位, 胆 管炎症の有無，程度等によるが，柽度の持続型黄㾝 高度の短期の黄㾝等, 璉 々の症例に上って，街後経 過に差異をみとめる。われわれは，術後経過，とく

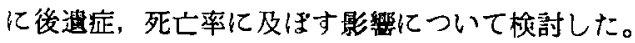
術前黄疸は胆石症, 無石胆要炎の約19.9\%にみとめ られ，かつ，䏣管結石，肝内結石例飞多いが，胆裹

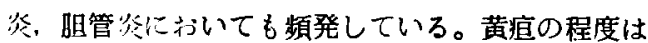

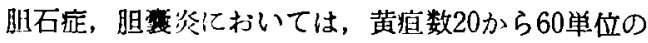
中等度黄痻例が多く，この持続期間も約 1 力月から 6 力月のきのが最も多い。また手術時に黄疸をみと めるものり他，既往において黄㾞の認められたもの 間歇的に黄疸の発生した例等, 黄疸の発生形式によ って細かく分けてみると，てれが肝障害さらに他臓 器に及ぼす障害の程度から，術後成績に大きな差異 をみとめろ。勗道の覀性婳晹ではやや趣きを異にす
ろが，いずれにしろ黄疸が，思者の予後を左右する 重要な因子であるととを强調する。これに加えて， 教室で释験した難治性黄疸症例について，その黄疾 の椂相，治療経過を報告する。

III-34. 外科的高度黄㾝の臨床経験

病院外科 ○杉 重喜 前田外吉男 杉山道雄 缡栖昭治 川口竜文 加藤金吾 村田 㲵

昭和 39 年 1 月上り昭 42.3 . 迄約 3 年間に睯友病院 外科で入院治療を受けた肝，胆道疾思は 120 例であ る。

結石 78 。朋, 胆道, 膵癌 15 。陶器梯胆裹 1 。石灭 乳䏣计 2 。慢性滕炎 2 。織胆管拡張症 1 。三の他手 術を受けず彰断不詳のもの。肝整腫等であった。

そのうち, 黄疸指数 60 以上の 23 例について顺討し た。

一般に胆石症ではMG，60以上は稀とされている か，78例中 8 例方 $\mathrm{MG}$ G0以上, MG80以上の高度黄 疸 3 例，MG 160以上の超高度黄疸 2 例が含まれる。 癌症例では, 高度, 超高度黄疸例が大部分であっ た。

外科的黄㾝鑑別に，尿ウロビリノーゲン，アルカ リフォスファターゼ, トランスアミナーゼ等が有力 であったが，血清コレステロール值上昇は指標とな らなかった。肝生検も高度持続性黄疸症例では鑑別 困難であった。

経皮的肝内胆管造影，及び膵管造影等が，診断， 手郝法選択等に有力であった。

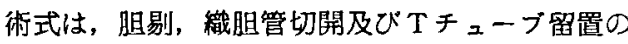
他，膵頭十二指腸切除 2 ，肝管空腸吻合 4 , 肝内胆 内胆管外㜢造設 4 , 肝内胆管空腸吻合 1 , 肝左莱切 除 1 , 践胆管十二指腸吻合 2 , 䏣婁空晹吻合 2 , 胆

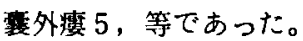

これ等の成，不成功例について検討したい。

III-35. 閉塞性黄㾝と術後堅噇害

\begin{tabular}{|c|c|c|c|}
\hline \multicolumn{2}{|c|}{ 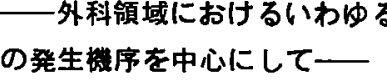 } & & \\
\hline 東大 石川外科 & ○荷見秋彦 & 玉熊 & \\
\hline 上原 健一 & 中山夏太郎 & 中野 & \\
\hline 山田 義晴 & 小泉 澄彦 & 石山 & \\
\hline 野呂 俊夫 & 田島 芳雄 & & \\
\hline
\end{tabular}

従来からわれわれは循環器系に関する手術前後の 病態を検討しているか，今回は開塞性黄疸の症例に みられる術後腎障害を中心に，外科領域にわけるい 
わゆる肝堅症候群の発生機序に関して㭘討した成績 を述べる。

過去10年間に訮胆道疾患の手術のために入院した 450 例中，臨床的に上記の肝腎症候群に属すると思 われる35例について検討すると，(1)その大部分は黄 瘟指数30以上の症例である。(2)動脈硬化性病変の強 い60才以上の症例が大半を占め，とれに反して若年 者では黄疸の強い症洌でも本症候群を示した者は極 めて少い。(3)ずれも手術侵膂乃至, 消化管出血, 腹 腔内感染，ショックなど重篤な合併症にひきつつい てそ尿乃至無尿に陥ったものである。てれらの事実 は外科領域における本症候群の発生に関連する因子 をある程度示しているが，この点を更に明らかにす るためまず，閉塞性黄疾の術後腎機能の推移を，内 因性クレアチニンクリアランス值, 術後最高濃縮時

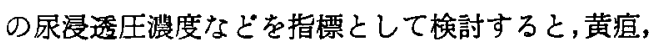
肝障害の程度と並んで, 動脈硬化症などの臓器の阻 血性病変も閉塞性黄疸の術後腎機能低下に明らかに 関係していることが認められた。更に総胆管結禁に より得られた央験的黄㾝犬に，30分間腎血行を遮断 し，解除後の腎血行動態を黄㾝を作らない対照と比 較すると，黄疸犬では腎血管抵抗が増大し，腎血流 の回復はあきらかに遅延することが認められた。

以上の臨床並びに実験成綘を総合すると，黄疸の 強い症例では手術侵襲や病单からの出血, ショック などの合併症を伴った際,容易に腎血流量,減少を招 き, 特に動眽硬化性病変のうたがわれる高令者で著 しいとと，ひとたび減少した㛑血流量は，黄疸例で はなかなか回復しにくいことなどが明らかにされた が，これらの事実は外科領域における肝腎症候群の 発生機序の解明役立つ所見と考える。

III-36. 最近 5 カ月年間に扱った胆道再建の症例に つい

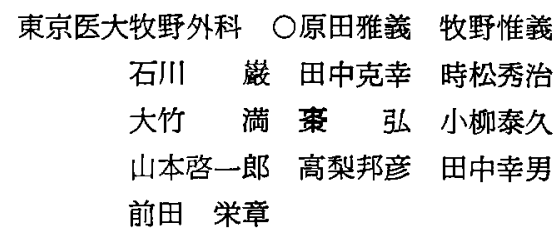

元来, 膵, 胆道腫瘍は黄㾝発現に伴い初めて気付 く場合が多く，往々にして手術時期が遅れ試験開腹 に終る場合がある。又例え行元ても，術後の出血， 肝腎症候群合併，他䁍器の転移，要液質等により死 亡することが，殆んどで，長期生存は極めて少いと されている。術式も部位により非常に至難で外科医 を悩ます場合が多い。
我々の教室で扱った昭和37年より昭和 41 年迄の 5 年間の此等疾患 75 例について, 疾患別, 年令, 性別 入院期間，末佾一般，肝機能， $\mathrm{X}$ 楾所見, 生存期間 術式等について比較検討を試みた。

疾患別では，75例中膵癌39列52\%，肝癌18例 $24 \%$ 胆道癌11例 $14.6 \%$ ，䏣震癌 7 例 $9.3 \%$ であり男女別 では，男 41 例 $54.6 \%$ ，女34例 $45.3 \%$ で男子に稍々多 く, 年令別では51〜60才代が34.7\%で一番多く，次 いで61〜70才代が33.3\%を示していた。又75例中死 亡退院は約半数 44 例 $58 \%$ を示し死亡率の高い事を物 語っていた。術式により眺めると胆道下部, 総胆管 通管障得, 上部肝管等の胆道通過障害に対し,閉塞部 位に応じ種々の䏣道再建術を試みた。一番多いのは 試験切除 $25.3 \%$ 次いで䏣露胃吻合術 $12 \%$ 胆衰空腸吻 合術 $9.3 \%$ 順で, 特に上部肝管の腫痬による, 狭 窄に際し全身状蕜の急激な亜化に伴い，肝瘻造設の みを行った例がある。この例は意外に長期延命効果 を䜑め, 黄疸も消失, 手術の目的を達したが, 癌の 肺, 腹腔内転移により, 悪液鬲を生じ死亡した。

尚, 予後の問題については昭和 42 年度症例も加え 目下追究中である。

III-37. 閉塞性黄㾝に対する胆道再建術

富山市民病院外科 ○北川 謷 木南義男 森田弘之

最近 2 力年間において, 肝䏣道系疾患手術施行 91 例であり，内黄疸を主訴として手術施行したもの は, 34例である。

良性疾患による䏣汁排出障害は16例, 悪性腫晹に よる明汁排出障害は19例である。

この悪性腫瘍による䏣汁排出障害に対し, 根治的 切除術を施行する事は勿論であるが，根治術不能例 に対しては，出来得れば，黄疸軽減手術によって延 命効果を計るべきであろう。

我々は根治術不能例に対し，䀒外胆管利用例は 9 例で，内 1 例は䏣管内T字管插入法を施行してい る。一方肝外胆管利用不能例に対しては, 肝腸吻合 術を施行しており，乙の肝腸吻合術について検討を 加えたい。

肝門部董啺に対し, 黄疸軽減効果より見れば, 䏣 汁誘導排出口が大なる程有効なのは, 当然であるが 腫湯の位置, 浸潤度より，肝門部利用よりは寧ろ， 尰猲を離れた肝縁を選ぶべきであり，我々は左肝部 分切除を行ない，肝内胆管径 3 mmのも 2 本を, 又 他症例ではネラトン 8 号カテーテル插入可能な拡大 肝内䏣管を利用し共に满足すべき黄㾝軽減效果を認 
めている。

又合併症としての上行感染に対して, Roux en $\mathrm{Y}$ 腸吻合衍は勿論の事ではあるが，更に肝内胆管の切 離断端を肝切離面より約 $0.5 \mathrm{~cm}$ 残存遊離せしめろ事 に上り，腸管内圧穴進による逆流現象，上行感染を 防止し得ている。又更に肝切離面に表われた，他の 䏣管に内㹩 $0.2 \mathrm{~cm}$ のポリエチレンチューブを挿入固 定し，街後の肝内䏣管洗涤用に利用している。

艇合不全対策としては，漿膜縫合系を残存し，全 周に大網を縫着する事により防止し得ている。以上 てより我々が今迄に施行した肝腸吻合術にて充分满 足すべき黄㾝轾減効果を得ているので報告する。

\section{III-38. 胆辁十二指晹吻合訹の遠隔成縝}

川崎市立病院外科 ○斉藤敏明 石田堅一 新井松雄 津村 整一色 昇 松田博青

昭和30年以降, 我々は 164 例の胆表十二指腸吻合 術を行った。そのうちわけは，胆石症 110 例，䏣倳 炎17例, シスキネジ20例, 要性腫湶 9 例, その他 8 例である。

死亡は14例で, 悪性腫煌の 9 例と䏣石应で手術後 に発生した癌によるもの 2 例, 詳細不明の死亡 2 例 である。

手術死亡は 3 例 $(1.8 \%)$ て，てれらはすべて悪 性腫湯で高度黄㾞を伴っていた。

アンケートにより遠隔成積をとり得たのは97例で このうち約 $80 \%$ 亿好結果を得ている。

成續不良のものは12例で, 胆石症 8 例, 胆隻炎 2 例，ジキネジア1例，その他 1 例である。

これらの症状は疼痛のみ 2 例, 発熱のみ 1 例, 疼 痛之発熱 2 例, 疼痛と黄痽 2 例, 発熱と黄㾝 1 例, 疼痛発熱及び黄瘨を来したもの 4 例である。

これらのうち8例か再手術を受けており，その原 因としては再発之考えられる助石 4 例, 上行感染と 考えられるもの 1 例, 腹腔内の陳旧性膿瘍 1 例, 䏣 表癌併発 1 例, 不詳 1 例などである。

再手術の術式としては, 閉塞した吻合部の再吻合 術 2 例, 䏣零剔除術 2 例, 吻合部離断閂鎖 1 例, 単 開腹術 2 例, 総胆管切開截石術 1 例などである。

再手術後の成績は 6 例がほぼ良好で，1例は不良 䏣震癌の 1 例は死亡した。

III-39. 良性胆道㹧窄に起因する肝脾の变化

京大 本生外科 ○小林克满 水本竜二 良性䏣道狭窄のなか沈発熱, 黄㾝, 疼痛等の 発作をくりかえしつつ遂には肝脾腫, 食道静脈瘤等
をともなった門眽压穴進症や，肝病変の遷延化をし めす症例があり，従来所内細䏣管の閉塞，断裂や， 長期にわたりくりかえされた胆管炎等が原因と考え られてきたが，更に免度学的機序や橧機能六進等の 関与も考慮される。

われわれは他医で胆裂剔出術にさいして誤って胆 道損傷をうけ，術後閉寒性黄疸，又は胆汁瘦をきた して来院した8例にたいして胆道再建術をなこない 最長 9 年間にわたって経過を観察しているが，かな り高率に門脈圧六進症状の発現をみとめており，又 閉塞性黄㾝をともなった総胆管結石の症例で脾腫を みとめ，あるいは結石剔出後充分に胆道開存を確認 したにもかかわらず黄疸軽減の遥延せる症例を経験 している。

われわれはこれらの症例にこられた良性胆道狭窄 に起因する門脈圧六進症ならごに肝病変要延化機転 につき若干の検討を加えたので報告する。

III-40. 胆道消化管吻合術後患者のX線所見につい ての考察

国立名古屋病院外科磯部吉郎

演者が国立名古屋病院にわいて最近 7 年半の間に 行った胆道消化管吻合術は62例であり，術後 X線検 查を以って追究し得た症例について模討考察した。 単純X線撮影によって肝内胆道に腸管由来のガス像 を認めたものは31/33であり, B a 粥撕取による B a の胆道内逆流を認めたものは $9 / 31$ であった。総胆 管十二指腸吻合術後ではガス像は $14 / 15 ，$ B a 逆流 は $7 / 13$ ，同空腸吻合術後ではこれぞれ $16 / 16 ， 1 / 16$ （ルーY吻合肛門㑡の腸管痻着のあった 1 例）であっ た。空腸吻合（ブラウン加）てX線検查時にブラウ ン吻合肛門側腸管を強く圧して B a 通過に抵抗を与 えることによって B a がブラウン吻合部から胆道吻 合輸入脚を進行して胆道内に流入するのを認めた 1 例があった。十二指腸で B a 逆流の認められたもの はすべて桧査中には何ら操作を加えなかった。結局 空腸吻合の方が下部腸管の通過障害のない限り B a 逆流ひいては逆行性感染に対しては安全であると考 える又 $\mathrm{X}$ 線検査時の体位の変换によって胆道内ガス 像の增減が見られ，更に B a 逆流はこ机と反対の增 減の留度を示していることを知り，加うるに体位に よって逆流した B aが容易に腸管内に還流し得るこ とを知った。即ち B a 逆流は立位では少なく，これ より仰卧位になると急激に増加し，こ引より立位に もってゆくと著しく減少する。とのととから吻合部 は可及的大きく造設するのがよく，且術後患者には 
食後若干時間は仰卧位をとるのを避けしめるのがよ いと考えら机る。又, 症例の多くは深呼気時の方が 深败気時よりも胆道内ガス像の量が多いようであっ た。胆道消化管进合術後の逆行性感染防止の観点加 ら令後一们この方面で追究侩討を行う必要があ ると考える。

III-41. 先天性胆管事腫症 5 例の検討 㕕島大 上村外科 ○岸 明宏 石井哲也 㮖山 隆 田辺良二

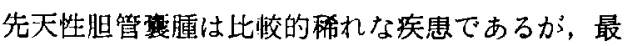
近 5 年間に我々は 5 例の本症を経験した。初めの 2

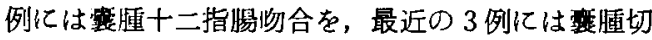
除陽管Y字沕合術を施行したか，その術後経過，切

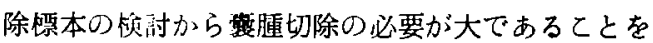
述へ，同時にこの晾断，特に先天性胆道閉鎖症との 鑑別にスーパーセノグラムが有効であることを報告 したい。

III-42. 先天性総胆管拡張症に合併した胆衰捻転症 の 1 例

東京撆察病院外科 ○佐久間崇 若林利重 斉藤慶一 新谷義克 吉川一彦 日下史章

先天性総胆管拡張症は本邦ではさほど稀な疾患で はなく，私共も最近 3 年間に 4 例を経験している。 胆慧捻転症は比較的稀なものとされ本邦においては 30余例が報告さ机ているにすぎないが私共は本症の 2 例を経験している。このうち 1 例は総胆管抎張症 に胆数捻転症を合併した桸有な症例であるのでここ に報告する。

症例：4才女子, 3 才頃より䅉々食後上腹部の疼 闹を訴えていたが，昭和39年 6 月28日激烈な腹痛と 呕吐のため数急車にて米院。高熱, 白血球增多，上 腹部の著明な压痛を認めたが黄㾝はない。経過を観 察したが入院後 3 日目より腹捎, 呕吐堌前し腹部全

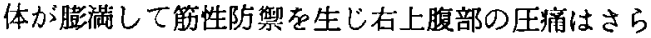
に活くなってきたので穿孔性虫正炎の診断で開腹し た。牌腔内には胆汁様㳙出液が多量に眝留し約 1,000

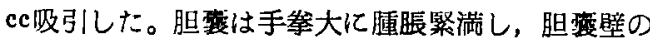

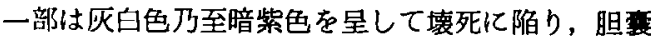
管は時計の針と同方向に $180^{\circ}$ 捻転していた。しかも

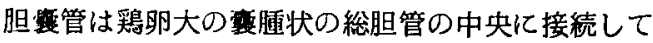
おり，先天性総胆管㹡張症に合併した胆裂揄転症で あろことがわかった。この時は急性腹膜炎の症状が つよいため㫜剔のみを行なった。退院後いつもアル カリフォスファターゼのみやや高值を示した。昭和
42年 2 月15日（前回手術後 2 年 8 力月，患者 6 才） 以降時々上腹部㾢が現われるようになったので 3 月 13日再開腹。総胆管は前回手術時と全く同じで酦婳 状拡張を呈していた。售腫内の仕は初圧 $8 \mathrm{~cm}$, 安定 死15cmであり，術中胆道撮影像汃らも胆汁の十二指 腸内への流出が不良であることがわかった。総胆管 震腫十二指腸陋合施行。

胆裂捻転症は移動性胆軎という解剖学的異常に何 らかの誘因加加わって発生するといわ机緊急手術を 要する。本应例では胆亳は殆ど旰下面に着休してい なかった。また総胆管拡張症は放置すれば予後はわ るいといわれている。本例は術後経過るよくアルカ リフォスファターゼも正常值に復した。

III-43. 先天性胆道閉鎖症の術後成績について 一一特に其の予後を決定する因子について の検討一

九大 西村外科 ○馬渡康郎 志村秀彦 小谷㮔治 安部隆二 古賀明俊

教室に於ける先天性胆道閉鎖症手術例35例に就い $\tau$ ，臨床検查成積殊に黄疸の程度，手術時年令，病 型，所組織像，手術術式と術後成績について検討し 予後を左右する因子について検索を加えた。

35例中27例に術中所パイオプシーを行ったが，軽 度の肝線維化が認められたものから，著明な肝硬変 症を呈したものまで種々ありこれらをその程度に より 4 型にわけて㭘討を加えたが，手術時年令の高 い程所線維化が強く，従って術後成結が不良であっ た。

吻合可能型 4 例中 3 例が生存し，黄疸の完全消失 を認めた。吻合不能型の中15例に肝門十二指腸吻合 ナイロン糸誘導を行ったが中 5 例が生存しており （最短 3 力月より最長 2 年半にわたって）中 2 例に 黄疸の完全消失をみて居る。手術時黄疮についてみ れば，黄㾝指数50以上の症例17例中13例 $(76 \%)$ か 死亡しており黄㡺指数 50 以下の症例 9 例中 4 例 (44 \%) が死亡している。

III-44. 腹腔内荿器奇形の稀有なる 2 例 岩手県花巻病院外科 ○池下一也 佐藤 進

私共は最近大，小網奇形および総胆管奇形の稀れ なる 2 例を経験したので報告する。

症例 142 才 男

突然の激しい上腹部痛, 呕吐を訴え, ショック状 態で来院した患者であるが，腹部は全体に膨满し， 上腹部に著明なデファンスおよび压消が認められ 
た。捅穿孔性腹膜炎つ診断で開腹するに横行結腸間 膜を認めず，横行結腸は腹腔後壁に固定されており 大網は横行結腸に附着せず，遊離の状態で網震底部 は形成されていない。小網は肝十二指腸および橫谝 胃部の一部を認めろのみて， この大部分が久除して おり，小腸が胃後方を通り，小網欠損部より前方に 出て腹腔上部を占有していた。

なわ，十二指渴前壁に $2.0 \times 1.5 \mathrm{~cm}$ の穿孔を認め， 組織学的に慢性漬痬ておった。

症例 241 女

急性の腹痛と発熱を泝えて来院した患者であるが 臨床診断の結果急性膵炎として治療した。释過中右 季肋部に表在性の腫瘤を触れ，また胆㸺，胆道レ線 像で高度の総胆管拡張がみられたので, 特発性総胆 管拡張に合併した腹部腫湯の診断で開腹した。開腹 の結果腹部置瘤は滕静脉索に一致し上方は肝門部に 附着していた。また総胆管は高度に拡張していた。 腹部茞瘤は組織学的に臍静脉索周囲の脂肪租織の胆 汁性壊死によるものであり，術後の経総胆管性胆管 造影で総胆管の高度拡張がみられるが, 肝内胆管に は左程の搪張はみられず，また抎張した総胆管の下 部から胆道は二股にわかれ，一つはそのまま下降し て，十二指腸に開口し，一つは正中側下方に向かい 次いで反転して右上方に向か心，前述の胆道と交攴 してこの開口部上方で十二指腸に開口寸る。

したがって本症は総胆管奇形を伴なった胆汁漏出 による臍静脉周囲脂肪壊死症と云うべき極めて稀れ な症例と思われる。

\section{III-45. 肝空に対する肝切除}

京府大 第 2 外科 ○刍井 普 金井広一 黒岩延男 寺村幸雄 北川司良

進行肝癌に対する拡大肝切除の9例を合めて，教 室で行なった原発性ならびに転移性䏦癌の手術につ いて報告する。

手術法としては肝動脉内插管により，色素を注入 して肝実賈を着色し，切除籍囲の解剖学的関係を明 らかにしたのち, 肝動脉, 閒脉を一時的に遮断して 冷却ブドー糖液を潅流し，局所的に肝令却を行ない つつ切除操作を進める方法をとっている。

この方法によれば䀒莱の限界をこえて進展した肝 癌の切除も比較的容易に行なわれ，肝命却ならびに 実賈内血液駆出により，切除操作中の出血を䓔しく 堿少させることが出来る。

さらに切除に先立って肝動脉内に大量の制癌剂を 注入することにより，極めて悲観的と考元られてい
ろ肝癌に対方る肝切除の成績を向上させることが期 待される。

術後好置としては, 総胆管内に $\mathrm{T}$ チュブを留置 して胆管内圧の低下を計り，同時に肝排泄機能を継 続的に観察することに重点をおくはか, 残存肝の蛋 白合成機能低下に对しては, アルブミンの点滴, こ の他積極的な颀置を行なっている。

切除肝癌は重量2000 gを超える巨大肝腫痬の 4 例 をはじめ, いわゆる広沉肝切除に属するものが多か ったが, 手術应例のうち4例は, 現在なお健在であ り，このうち最長生存者はすでに術後 29 力月をてえ ている。

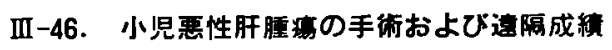

東大 第 2 外科 ○省藤純夫 石正田統 角田昭夫 三浦 健 佐藤富良 室井竜夫 堀隆 土田嘉昭

小韭期の肝悪性腫瘍10例について，手術成續およ び遠陑追跡成績, 術後抗癌剤, 放射線療法の結果を 検討した。

症例の手術時年令は生後 3 月から 6 才10月，男児 7 例，女归 3 例である。症状は肝腫脹を主訴とする 他, 特異所見はなく, 発病時期は明確でない。

術前検查は肝超音波エコー，肝シンチグラム，肝 動脈撮影が腫瘍の進展範西を决めるのに有用であ る。

手術術式は左葉切除 3 例, 右葉切除 1 例, 試験開 腹 6 例であるが，肝全葉に侵閵し，切除不能例に対 し抗澏郕 (5-F U) の肝動脈内持続注入を施行し二 いる。手術成䅡は生存 5 例で，この長期生存例は肝 右葉全切術後 3 年 8 力月の hepatoma, 肝左葉切除 術後 2 年10月の hepatoblastoma, および単開腹䌸 故射楾照射後 4 年の hepatoblatema で，各れ 在である。

組織学的所見は hepatoma 4 例, hepatoblastoma 4 例, Kupfer 細胞肉腄 1 例, haemoangiopenicytoma 1 例である。年令と租織学的特徴との間には 有意の相関はない。

手術成績からみて小坚期の肝悪性缸瘍は左右葉に 限局している例に対しては積極的肝亲切除を行うべ きである。両葉に進展し, 切除不能例に対しては, 肝動眽内の抗癌剤（5-FU）の持続注入わよび故射 線療法を行う。

㭃児期に手術を行った症例でも神経牙細胞腫, Wilms 腫痬に比較し，手術成績は良好である。これ は転移少よび肝機能障害 (肝偭変) の発現率の低い 
こと, 胎生期肝細胞の未熟残存性增殖 (組織学的所

見）など成人肝悪性腫漡と異なっだ特徴をもつため と考えられる。

III-47. 幼児 fetal hepatoma の肝左葉切除による 治験例

横浜市長津田厚生病院外科 ○鈴木孝雄 小野久弥 坓原光夫 小沢西郎 山口宗之

幼児および小児の原発性肝癌は比較的まれである が，本邦に於ては60数例の報告があり，近年増加の 傾向にあると思われる。統計によると，2才以下が その過半数を占め, 性別では男子に多く, 肝右葉に 好発する㑯向がみられる。

我々は最近奻児原発性肝癌に対し肝左萧切除に成 功した一例を経験したので報告する。

症例は 1 才 3 力月の女子， 4 月 7 日祖母が腹部腫 瘤に気付き来院, 来院時自覚的所見なし，体格小， 栄養やや不良であるがるい溲はない。体重は7.5kg。 左上腹部に超手拳大の腫瘤を触れ，可動性良好。諸 検查を行うも著変なし。4 月24日開腹，腫溜は肝左 葉に限局し，附属リンパ節の腫脹はみられなかっ た。鎌状靬带の左側健常部にマットレス稌合を行い 肝左葉を切除，断端の血管，肝内胆管の結禁を十分 に行う。

術後経過良好で 2 日目より平熱とふり, 経口的栄 稳開始す。30日で体重増加500 gがみられ，現在故 射線療法施行中である。

病理組織娭查の結果は fetal hepatomaであっ t。

III-48. 肝硬変性食道静脈㾇出血の赛態とその外科 治療の要点

九大 井口外科 ○真鍋博史 井口㵖 小林 迪夫 前山隆太郎 浜武 義征 小川学一郎 朔 元則 椎崎 敏臣

肝硬変性食道静眽溜出血は近年益々增加の㑯向に あり，しかも，一旦吐血すれば吐血死の危険は勿論 既存の肝障害堌瑟もあって，ちの予後甚だ不良であ る。

食道静脈瘤出血に対する内朴治療の効果は期待し 難い場合が多く，一方，門眽下大静脈沕合術を中心 とする外科治療も本邦旰硬変症の特異性つため, 欧 米のそ扎と比校し死亡率も高く，必ずしも满足すべ き成綨をあげえていない実状である。したがって本 症に対士る外科治療成績向上のためには本邦所便変

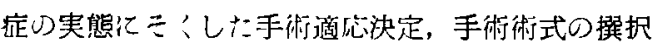

工夫等について慎重な検討がなされなければならな W。

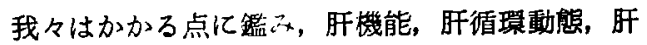
硬変組織型等を総合的に考虑した一定の手術適応基 準を定め，手術術式も個々の症例に応じて，噴門切 除術或いは controlled splenorenal shuntを行うよ うに規定し良好な成績をあげ得ていろので，今回は 我々の治療例も含めて内科治療例84例, 外科治療例 108例，剖検例46例，計238例の䀒硬変症例について 検討を加え，本邦肝䃘変症の特異性，特にその食道 静眽瘤出血の実態につき報告し，并せて予後を良好 ならしめるための外科治療方針についての我々の工 夫と見解をのべる。

III-49. 肝部下大静脈閉塞症の3 治険例

$\begin{array}{ll}\text { 慶大外科（赤倉） } & \text { 畈田光三 石倉義弥 } \\ & \text { 須田英明 井上 正 } \\ \text { 静岡赤十字病院外病 } & \text { 小田 豊 永井 泉 } \\ & \text { 小平 進 }\end{array}$

所謂 Budd-Chiari 病，或いは Budd-Chiari 症候 群之総称さ扎ろ疾患中, 肝部下大静眽閉塞症は，19 61年木村教授により，手術方法加発表されて以来注 目され，外科的根治手洐症例が報告される様になっ た。

われわれは最近 3 例の肝部下大静脈閉塞症を释験 し，何れも外科的根治手術を施行して治㦄せしめた ので報告する。

应例 149 才男で発病後20年を程過しており，静 脈撮影により, 右肝静脈開口部直上に小開通孔を有 する膜様閉塞があり，本症で盲目的膜破砕法によ る肺栓塞の危険を考え，体外循環下に膜裂開，切除 を，更に左肝静脈閉突部を除去，開通せしめた。術 後経過は良好である。

症例 248 才男て， 7 年前より高血圧及び留炎と して治療。静脈撮影により旰部下大静脈閉塞症と診 断された。閉塞部は膜様と考えられ，用指膜破研術 を施行した結果，略容易に裂開可能であり，歪虑す べき血栓の存在も認められず，体外偱環を使用せず 手術を終了した。術後, 腹水消失し, 血死正常とな り良好な経過を示している。

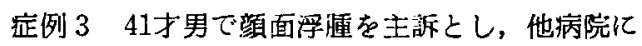
て綐隔腫痬による上大静脈应候群として開胸手術を うけたが，上大静脈閤塞のてのため，このまま閉胸 した。術後腹水を認める㺊になり来院，上下大静眽 撮影の結果, 上下大静眽閉塞を認めた。下大静脈閉 等部は右肝静脈開口部直上にある膜様决乍で，上下 
大静脈間の著明な側副血行を㤮めた。手術は下大静 眽狭窄部を用指裂開し, 更化上大静脈閉塞部を再建 せんと試みたが不能の為，下大静脈への側副血行に 期待して手術を終った。術後顔面浮腫及び腹水は消 失し，現在頸静眽の柽度の怒張を認めるのみ下，極 めて順調である。

以上われわれの経験した肝部下大静脈閉塞症 3 列 つ経心房的膜破碀手術治駼例を報告するとともに， 診断及び手術方法について若干の考察を加えて報告 する。

III-50. 原性便化性胆道资と考えられる1例 质島大 上村外科 ○高井志郎 沖井洋一 慢性便化性胆道炎は原因不明のまれな疾思で誩断 及び治療が困難で有る。

最近我々は 19 才男子で外科的黄疸として開腹術を 施行した症例でその手術所見より慢性硬化性胆道炎 と考えざるを得ない1例を経験したので，臨床症状 及でニの祅断的根执を中心報告する。

III-51. いわゆるバンチ病の成因と手術法について 德島大 井上外科 O武久一郎 矢毛石陽三 越智 友成 北条 和陖 宮里覀三郎 吉田冲

本心や経過つ異なる疾患群の呼び名である閒脈圧 六進症の外科治療は，原疾恩の臨床的特性に立脚し た吟味と工夫がなされるべきとの立場から，私ども は過去数年来, 肝硬変症の脾腯，いわゆるバンチ病 脾循の摘脾前後の病龍生理, 脾血管の microangiogram，皆顕像を中心に検索を進めているが，今回 注手術成䋹，遠隔成程を检討して，いわゆるバンチ 病の手術法について $2 ， 3$ の知見を得たので報告す る。

1）摘脾前後の門脈圧の推移では，いわゆるバン 千病で压下降が著しく, 肝硬変症では $50 \mathrm{~mm} \mathrm{H}_{2} \mathrm{O}$ 前後 の圧下降に過ぎなかった。いわりるバンチ病を肝病 変別に分けて検討しても，硬変の有無に拘らず圧下 降が大であった。

2）脾血管の microangiogram の観察わよび脾動 脈撮影所見では，いわゆるバンチ病で，脾動脈の届 曲蛇行, 睡柱動脈の急激な細小化，細網間潦眝溜像 の点状陰影化，筆毛動脈，沪胞動脈の届曲蛇行など が特長的所見としてあげられる。電顕像でもうつ血 脾といゆるバンチ脾では䧺巽がみられた。

3）わゆるバンチ病，脾機能六進のある肝硬変症 の何れに対しても，摘脾わよび胃冠状静脈切除術を 施行して愉討したが，手術死亡率，遠隔生存摔，術
後再吐血率, 食道静脈濆改善率, 血液わよび肝機能 所見, 就学状況などに差がみられ，脾性因子に立脚 したいわゆるバンチ病の摘脾効果がかなり良好であ るととを知った。

4）改密に各種所見から新断分類されていたいわ ゆろバンチ病の手術法は，摘脾を根幹と寸る術式で はぼ充分の成績が得られるように思われる。

III-52. 諸種血液疾患に対する剔脾の治灰成績につ いて

阪大 陣内外科 $\mathrm{O}$ 門田尚武 藤田 正 小早川清 正稙 阪本俊一 村上文夫

当科において剔脾を施行した本態生血小板诚少性

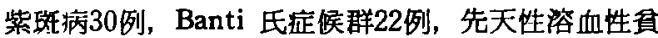
血 3 例，再生不良性䨘血 4 例，Gaucher 氏病 1 例， amyloidosis 1 例, 肝硬変症 7 例, 計68例について 治療成績を梌討した。

本態性血小板堿少性紫玟病にわけ万剔脾後の経過 は一般に良好で，30例中28例に出血症状の消失また は著明な样快が認められた。これら有效例の過半は 術後短時日のうちに血小板数の增加之筒噵像の改善 を示したが，血小板数がさはど增加しふい症例にお いても，血小板機能の改善が怹められた。術後 3 年 以上経過観察をおこなった16例のうち，重䉆な出血 症状の再発を訴えたもりは皆無である。剔脾が全く 無効に終ったのはわずか化 2 例で，いずれも術後 2 年前後に死亡した。これら店例について，剔脾後に わける出血症状あるいは血小板数の変動と，術前に おける骨蹃像，抗血小板抗体の有無，剔出脾の重量 副脾の有無，年令などとの関連を模したが，現在の ところ密接な相関は認められていない。

なお，現在 Banti 氏症候群その他の疾患における 剔脾後の経過を調查中でありここれについてもあわ せ報告する。

III-53. 各種血液疾患に対する剔聘の経駼

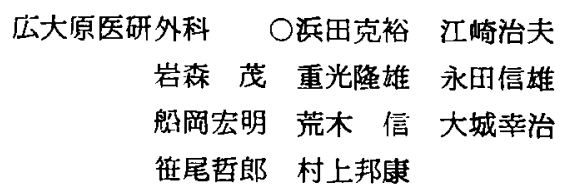

我々は特発性血小板减少性紫棞病及び所謂バンチ 氏症候群を始めとする種々の血液疾患に対する手術 経験から，原疾思に対する内科的治療，引続いて剔 脾を行う場合考虑すべき問題点並びにその治療勃果 亿つき報告する。 
III-54. 溶血性空血：剔脾による同一家系の 4 治誒 例

肢皁県美湍加茂市 近藤外科 ○近藤健吾

演者らは，31才，27才，21才の 3 名の姉妹とたの 伯父の子である26才の女の合計 4 例に先天性溶血性 貫血を䛦断し 4 例之もに近藤外科医院において剔脾 術を施行し症状消退改善の卓効を得た。2例に発症 の動機と思われる内科的疾患を認め，全例成弱体實

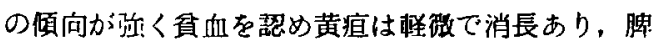
腫を 1 例に触知し他の3 例ではX線梌枯で䏦による 胃の内方圧排を認めた。赤血球数， $\mathrm{H} \mathrm{b}, \mathrm{H} \mathrm{t}$ の高 度の減少, 網状赤血球数增加, 赤血球の有核, 多染 大小不同，変形，骨铕像にわける Erythropoese の 異常なえ進，血清間接ビリルビン増量を認めた。何 れも Coombs テスト陰性であった。剔出脾は360〜 $660 \mathrm{gm}$ - 2 例に副脾を認め，1例に胆結石の合 併を忍めた。術後全例が黄疸消失し貧血は去り各種 検植成綪扩よび骨䯣像所見は正常もしくは正常に近 く復しだ。

演者らは，手術時の留意事項として，全穈下にO ${ }_{2}$ を充分に与をること，聘門部処理に当っては先ず第 1 に若し、は可及的早期に嵱動脈結禁を行うこと， 輸血は脾動脈結禁前には絶対に行わぬとと，副脾の 摘発に努め之を決して見逃さずに剔除すること，胆 石认仔自:ついて僻讃すること，を必ず行って来 た。このことを础調したい。

尚，後天性の本症と思惟された30才男の負血，峰 度黄痽患者で各種众查の結果として剔脾術を行って 黄疸と負血に效果の始ど羿められなかった 1 例があ つた。診断学的に尚一周の梌討の必要があるもしと して追究中である。

III-55. 这伝性球状赤血球症の!治駼例 山口県立中央病院外科 ○本田 迩 大滕 芳 河野 均 松田正名 遺伝性球状赤血球症は欧米に多いことは，よく知 られているか，本邦における報告は，比較的少い。 特に本症小㸺に対して脾剔を行った症例は30数例に 過ざない。吾々は本症小児の 1 例を経験し，脾剔に

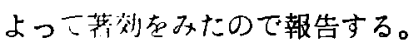

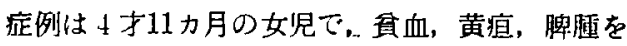
主訴とし，赤血球抵抁減弱，Price-jones 曲楾左偏， 網状赤血球增多，省髄赤芽球增多，球状赤血球症を 有し，クーム試験陰性，寒冷溶血素，凝集素，温 暖溶血素, 凝集絭, 何れも陰性で，3才の頃加ら虚
弱，荅白で，これまでに所謂クリー七と思はれる著 作がふられた。 $16.0 \times 10.5 \times 4.0 \mathrm{~cm} 350$ gの脾を剔出 したが，組織学的には，㙞链は赤血球で充满し，軽 度の線維化があり，腷洞洁はとんど空虚で压迫され ている。

術後は負血はなくなり，血清ビリルビンも正常と なったが，赤血球形的は程度は軽くなったけれども なお球状で，赤血球抵抗も，やや減弱を呈してい る。

術後 4 力月の所見は赤血球 $467 \times 10^{4}$, Ht $32.7 \%$, $\mathrm{Hb} 11.8 \mathrm{~g} / \mathrm{d} \ell$, ビリルビン0.35 $\mathrm{mg} / \mathrm{d} \ell$ である。

なお本例では，家族的関係はみとめ難かった。

III-56. 過 Insulin 症 2 治稌例の術前術啳 群馬大 藤森外科 ○瓷場生一 藤森正雄 泉雄 勝 曰井 亩 戸塚茂男

膵藏う氏島の意義は糖尿病において周知であろが 内分泌活性を示すラ氏島湩惕では低血糖症状によっ て臣床症状は複雑に修飾される。

本邦における本症非報告例を含めれば 100 例にも 及ぶが最近では Insulin の测定と柏俟って糖代謝い 動態，精神症状の病態，などが追㚾し易くなってき ている。さらに手術の結果屆瘍が見当らず組織学的 に肥大增生を示寸症例も10例程に認められてきてい る。

演者らの第 1 例は51才の主婿で臨床症状, 諸検査 成縝から insuloma の診断で手術を行い膵尾部に20 $\times 18 \times 16 \mathrm{~mm} の$ 腫瘤を発芫して剔除術と行い，組織学 的には腺腯と碓認された。術後の一過性血棈の後に 臨床症状も全く改善された。

第 2 例は41才の主㷌で「てんかん」発作を疑われ て精神科入入院したが過 lnsulin 症として当病へ紹 介された。本例も臨床症状，諸検查成結から膵䑏腫 痬を疑って開腹したが腄瘤は発見されず，腾頭部を 一部残して膵满要全剔除術を行った。その結果術前 の活い低血糖発作は消失し血中 Insulin 濃度も減少 したが術後 6 カ月を経過した今日時として轱度の不 快感を訴えることがある。

以上臨床的に Whipple's trias を示し諸検查成績 から興型的な過 lnsulin 症の 2 治験例々ついて術前 - 術中 - 淮後の末梢血, 門脈血 lnsulin 漶度の推移 や糖負荷試験, Rastinon 試験の意義 その他内分䎵 譏能について検討を加えたので報告する。 
III-57. インシュローム手術経検およびその術後合 併症について

横浜市大山岸外科 ○池田典次 米元敏崔 竹村 浩 逗藤 茂 有馬 甫 将基面值 久間祥多

我々が経験したインシュロームの症例の臨床経過 を報告するとともにその原後管理，術後合併症に関 し考察を加え参考供したい。第 1 例：57才 女

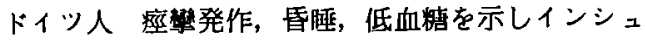
ロ一ムと診断。治療のため㷌国。第 2 例：41才，男 数年間両下肢のもつれ，意識の篲失あり，半年前か ら朝自然に覚醒しなくなった。空腹時低血糖（最低 $28 \mathrm{mg} / d \ell)$ を呈した。手術により膵頭部から Insulom （示指頭大， $1.5 \mathrm{~g}$ ) を剔出した。術後経過良好, 正 常し血糖值を示し，朝

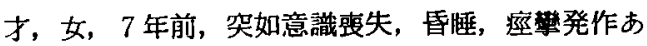
り，以後同椂の発作の反復をみ，低血糖（空腹時血 糖值20〜30 $\mathrm{mg} / \mathrm{d} \ell$ ) を指摘された。特発性低血糖症 として 2 回にわたり膵の部分剔除をうけ，症状やや 軽快せるも，朝の覚醒は，ブドー榶の注射あるいは 飲用によってのみ可能であった。3回目の手術によ って残存脺頭部より Insulom（拇指頭大, $3 \mathrm{~g}$ ) を 剔出し，術後朝自然に覚醒するようになった。しか し, 術值後から $600 \sim 700 \mathrm{mg} / \mathrm{dl}$ に達する高血糖か泏 現し，術後 5 日目に糖尿病性昏睡によると思われる ショックにおちいり無尿を呈して死亡した。剖検所 見では後腹膜腔への炎症の進展がみとめられた。以 上の如く第 3 例は，2 回の膵部分切除のため腫瘤剔 出後, 膵機能の欠損状態をきたし, 糖尿病性昏匡に おちいったと考えられ，これは術後の適初なInsulin 投与によって調整しえた䇢である。しかし剖検 によって確認された如き胶液漏出を基盤とする後腹 膜腔の炎症性病変はいわゆる術後合併症としては今 日まで特にあげられていないものであるが，ての診 断の困難さと予後山重大さの故につとに我々が上腹 部手術の街後合併症として注目してきたものに一致 する。

III-58. 興味ある経過をとれる膵頭部領域の疾患 京大 第 1 外科 ○若林陽夫 吉富錠二 中瀬 明 猿丸誠三 脺頭部領惐の疾患は，検查法の高度に発達した今 日なお鑑別猃断は必ずしも容易ではなく，又術後思 わ合併症に遭遇することもある。とれらの中で最 近教室で経験された興味ある経過をとった 4 症例に ついて埌告する。

\section{症例 1 77才 女子}

約 1 力月前加食欲不振，要捅を訴えて来院。入 院後急速に全身状態が垤化し，まもなく黄疸，吐血 意識障害を来たして，発病以来僅か 2 力月余で死し しだ。剖検で肝両葉に転移せる末期の脺頭部癌であ ることが判明した。

\section{症例 266 才男子}

約 6 年前から下血と胃部膨満感があり胃清痬と診 断されていた。約 2 カ月前から右季肋部の鈍饰を来 たし，肝榎瘤を指摘されていた。手術では胃小弯側 にくろみ大の腄瘤と所属りンパ節腫脹，肝転移を認

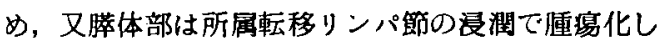
てわり胃癌の肝転移と思われた。術後吐血をくり返 し， 3 週間後に死亡。剖検で豚体部癌の肝転移と胃 潜瘍の合併例なることが判明した。

\section{症例 370 才男子}

2 力月前より閉塞性黄㾝を来たし，膵頭部癌の浐 断で胆露空腸场合術を施行。術後症状は泽快したが 脺頭部の迋瘤は一向に增大する傾向はなく，術後 200 日頃から食欲不振，るいたう，言語障害，次い で両上肢のけいれん，意識障害を来たして死亡し た。剖検で慢性膵炎と左頭頂菄の脳膙痬が 判明し to

症例 4 65才 男子 2 力月前より上腹部つ鈍痛 と膨满感があり，胃癌の診断で胃切除術を施行し た。汸中膡頭部に浸潤したえんどう大の転移リンパ 節を摘出したが術後12日目に急性膵壊死で死亡し た。

III-59. Zollinger-Ellison症候群の।症例

岡山博愛会病院 ○平松正勝 山口迪哉 私共は十二指腸潰瘍穿孔による胃切除後 (Billroth I ）物合部に再発せる難治性消化性漬瘍と胃液高酸 を呈した思者に対し，胃覀全摘出術と十二指腸粘膜 下に存在した屆瘦の摘出より，良好なる結果を得， 更に組織学的に Zollinger-Ellison 症候群と思われる 症例を経験したので報告する。

症例 : 65歳, 男, 漁師

主訴：胃部痛，下第

家族歴：父胃癌にて死亡，他に特記なし

既往歴：気管支喘息，急性肝炎

現病歴：昭和35年頃より空腹時固部痛，臌湍感お り。40年 1 月胃部痛弦度となり売薬にて辕快，その 後時々空腹時胃部痛あり。40年 5 月24日胃部激痛あ るため当院来院，穿孔性腹膜炎の診断にて值ちに開 腹胃切除術（ＢＩ法）施行，十二指腸溃湯穿孔性腹 
膜炎であった。修後経過良好であったが40年 7 月頃

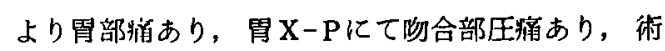
後消化性漬晹として治療する。その頃上り軟便, 下 寉が洔々起ころようになった。41年 6 月食欲不振,

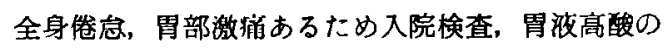
ため制酸剤，溃瘍治療剂投与に上り柽快退院する。 同年12月胃部啪，右下腹部痛あり急性虫重炎䎲て入 院, 虫切侕施行, 当時胃液は高酸であった。 42 年 2 月食不振，胃激消となり再度入院，胃X-Pにて吻 合部狭窄著明, 術後胃著明拡大を認め, 胃亚全摘 （胃十二指腸吻合術）施行す。乞の時十二指腸粘膜 下の腫湯と肝十二指腸靶帯上にリンパ腺腫脹を認め たのでてれを摘出しだ。組織診断にて isletcell carcinoma (non $\beta$-cell type) であった。尚現在外来 にて释過観察中である。

III-60. "Augmented" triolein testに関する研究

\begin{tabular}{|c|c|c|c|}
\hline 東邦大 & 大橋病院外和 & & 望月 彰 \\
\hline & 鶴見清彦 & 神公和明 & 門松拓郎 \\
\hline & 森田弘行 & 伊藤康一 & 小松邦也 \\
\hline & 宮崎隆司 & 恩田昌邦 & 上野昌 \\
\hline & E介 & & \\
\hline
\end{tabular}

膵智患に対する検査法には形態的変化を追究する 血管造影法， scaning，廻転横断撮影法等があり， 機能的変化特に外分泌面より検討する $I^{131}$ triolein test, pancreozymin-secretin-test, balance study 等 数多くの検查法があり, 我々は胆石症, 滕炎, 膵癌 に就いて，乙れら外分䎵面に於けろ検討結果を，本 学会, 日本外科学会, 消化器病学会等に於て報告して きたが，此等の方法には何れも長所・短所があり末 だ十分满足出来万状態とは考えられない。即膵液を 採取し，直接的に定量する pancreozymin secretin test も，兴便中の脂肪を化学定量する balance study も㭧者の苦痛, 操作の煩雑という難点があるので,こ れ等と代る方法として，J.Glass 等の “augmented” triolein test を検討した結果を本年 3 月消化器病学 会に於て紹会したが，今回は，“augmented” triolein test $\downarrow$ standard triolein test, pancreozymin secretin test, blance study を比較検討した結果に ついて述心る。即胃謴痬・胃癌等圊疾㭧群, 慢性膵炎 愺癌等膵疾息群, 胆石症, 胆道癌等胆道疾息群に大
別し，乙九等症例に上記諸検查を併用した結果を， pancreozymin secretin test 亿於ける 1）分泌量 と，2）重炭酸塩濃度と，3）トリブシンと，4) アミラーゼと, 5) balance studyと, 血中放射能 及び萁便放射能とに分類し, 相関関係の有無につい て検討したい。

又慢性膵炎・膵癌の術前・衍後 - 黄疸 - 腸切除 盲管症等80例に standard triolein test 及び “aug mented" triolein test 両者を行った結果，これ等 両者の比較により膵予備能を推定出来，膵疾患特に 慢性脺炎に於て吸収不全を改善することか特長と考 えられる。

III-61. Afferent loop syndrome

富山県立中央病院第 1 外科 $丁$ 広野禎介 富山道行 村田 勇

胃切除後症候群の 1 つとして, dumping syndrome と共に, afferent loop syndrome いろか，われわれも最近外科的治療を必要とした afferent loop syndrome 18例を経験している。

その内訳は acute form 3 例, chronic form 15例 であり，成因としては afferent loop 過長による herniation 又は kinking が多かった。

acute form 3 例は全例に afferent loop $の$ necrosis と急性膵炎の合併を認めたか;，壊死陽管の切除と共 にトラジロールを大量に使用することにより 3 例と も全治せしめた。

Chronic form 15例の大部分は，長期間にわたり 胆汁性呕吐を訴え，体重减少が著明であった。又 3

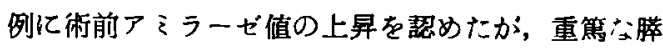
炎合併例はなかった。しれら chronic form に対し $\tau も$, afferent loop の再切除, afferent loop efferent loop との吻合など外科的治璄を行なうと同 時に，術後膵炎予防の目的でトラジロールを使用し 著しい効果を認めた。

以上,われわれの経験した外科的治療を必要よせ る afferent loop syndrome 18例に対し，この成因 診断並びに膵機能との関連性等につき臨床的に検索 をすすめると共に，ちの治療に関し榆討を加え報告 する。 